\title{
Restandardisation defined as democratising language planning ${ }^{1}$
}

\author{
Gerda Odendaal \\ Department of Afrikaans and Dutch, Stellenbosch University, South Africa \\ E-mail: godendaal@sun.ac.za
}

\begin{abstract}
The 1980s and 1990s saw several international political and social developments that gave rise to the ideology of democracy, which focuses on issues such as equal human rights and human dignity. Furthermore, globalisation gave rise to a worldwide ethnic renaissance with a focus on the nurturing of diversity. These developments led to the increased valuing and validation of variation, including language variation. Given this democratisation of the world, the relevance of standard languages, which are undeniably ideological in nature, is increasingly being questioned. Does a language variety which only serves the economic, social and political elite of a speech community still have a role to play in a democratic society? Or should we accept that this will inevitably lead to the destandardisation of languages? These are the questions that gave rise to discussions on the restandardisation of languages. The literature is, however, not yet clear on what is meant by restandardisation, as no unambiguous definition of this term exists as of yet. The aim of this paper is to give a clearer understanding of what restandardisation entails by discussing relevant literature on restandardisation, standardisation, destandardisation and other aspects of language planning in order to provide an unambiguous definition of restandardisation. By specifying its language planning and democratic properties, this paper aims to define restandardisation as democratising language planning, i.e. a language planning activity with the ability to transform the standard language in order to make it a democratic tool of communication that serves the entire speech community and in which all the speakers of the different varieties of a language are represented.
\end{abstract}

Keywords: restandardisation, standardisation, destandardisation, language planning, democratising

\section{Introduction}

Although standardisation has been defined, researched and expounded extensively in literature over the last few decades, the concept of 'restandardisation' is still a relatively unexplored area of investigation in sociolinguistics. Ferguson (1968, in Joseph 1987:174) and Joseph (1987) first used the term "restandardisation" decades ago, but without clearly defining it, and little

\footnotetext{
${ }^{1}$ This paper is based on my $\mathrm{PhD}$ dissertation (Odendaal 2012).
} 
has been written about it since. This has resulted in the lack of an unambiguous definition of the term.

The aim of this paper is to define "restandardisation" by referring to relevant literature on restandardisation, standardisation, destandardisation and other aspects of language planning in order to explain what I understand the term to mean and which aspects, in my view, form a part of it. This is carried out against the backdrop of a changing perspective across the world regarding standard languages and a tendency towards destandardisation. As an example in this regard, the focus falls upon calls since the 1980s from the Afrikaans speech community for the depoliticisation of Standard Afrikaans which have started anew in recent years ${ }^{2}$. By posing standardisation against destandardisation, the aim is to illustrate how restandardisation engages with both of these processes, but also differs from them, by defining restandardisation finally as democratising language planning.

\section{Background}

Since the 1980s there have been urgent calls from various sectors of the Afrikaans speech community that all varieties of Afrikaans should be included in the standard language. For example, Senekal (1984:219) asks for the recognition of the Afrikaans speech community in its entirety and the inclusion of other varieties in the standard language in order to reduce the gap between Afrikaans and its speakers. Alexander (1990:39) and Ponelis (1992:71, 1994:107) have indicated that Standard Afrikaans is merely one of many varieties making up Afrikaans. Van Rensburg (1983:24-25) argued especially for the other varieties of Afrikaans:

Hier lê 'n rykdom aan taalvorme wat wag om ontsluit te word vir gebruik in ons Afrikaans, en in die Afrikaans van môre. Die meeste van dié vorme is Afrikaans in murg en been - anders as die meeste Afrikaanse "slang"-vorme. Daarby kom nog 'n wins: hierdie vorme is lewende, egte, spreektaalvorme. Deur meer sulke vorme en konstruksies in Afrikaans te gebruik, sal die groot kloof verklein - die kloof wat bestaan tussen die stywe en onuitstaanbare formaliteit van $\mathrm{AB}$ [Algemeen Beskaafde]-Afrikaans aan die een kant, en die spontaneïteit en egtheid van die taalgebruik van die Afrikaans van baie nie-standaardtaalgroepe. ${ }^{3}$

Calls for the inclusion of other varieties of Afrikaans have been centred especially around those varieties that were previously marginalised - the varieties which had no chance of being included in Standard Afrikaans under apartheid rule. According to Ponelis (1992:80, 1994:118,

\footnotetext{
${ }^{2}$ Numerous symposia on this topic have been held in recent years: "Standaardtalen in beweging. Standaardisatie en destandaardisatie in Nederland, Vlaanderen en Zuid-Afrika" from 19-21 August 2009 at the University of Leiden, Netherlands; "Mainstreaming Afrikaans regional varieties" from 24-25 January 2011 at The South African Center for the Netherlands and Flanders, Pinelands; "Kaaps in fokus" from 19-20 July 2012 at the University of the Western Cape, Bellville.

3 "Here is a wealth of language forms waiting to be unlocked for us to use in Afrikaans and in the Afrikaans of tomorrow. Most of these forms are Afrikaans in their very fibre - unlike most slang forms in Afrikaans. Furthermore, there is the benefit that they are living, real, spoken forms. By using more of such forms and constructions in Afrikaans, a great gap can be closed somewhat - the abyss that exists between the stiff and unbearable formality of Algemeen Beskaafde Afrikaans ["Standard Afrikaans"] on the one hand, and the spontaneity and authenticity of the Afrikaans used by many non-standard language groups, on the other".
} 
1998:5-6), there is a diglossic ${ }^{4}$ relationship between the standard variety of Afrikaans and its vernacular due, in part, to the ideology of Afrikaner Nationalism which alienated a significant number of Afrikaans speakers from Standard Afrikaans by means of discrimination. After the South African War (1899-1902), Afrikaans increasingly became a symbol of the Afrikaner ${ }^{5}$ battle for recognition as a nation. Afrikaans became a cornerstone of Afrikaner Nationalism during the formation of Afrikaner cultural organisations such as the Federasie vir Afrikaanse Kultuurvereniginge ("Federation for Afrikaans Cultural Associations") or FAK - "the rallying call of the Afrikaner nation and the basis on which the Afrikaners intended to take control of the government" (Degenaar 1978, in Davids 1987:57-58). However, the subservience of many erstwhile Afrikaans institutions to the apartheid government, to Afrikaner Nationalism, and to apartheid itself, disconnected Standard Afrikaans from a large and growing part of the Afrikaans speech community and the people of South Africa as a whole (Ponelis 1992:79, 1994:117). According to Ponelis (1984:38), the linguistically conservative power of Afrikaner Nationalism only mobilised the Afrikaners in the speech community, while alienating coloured ${ }^{6}$ speakers. Therefore, Afrikaner Nationalism played a part in the standardisation of Afrikaans (Ponelis 1987:13). Calls for changing Standard Afrikaans thus imply the redefining of the language in order to correct the political injustice ingrained in its very fibre. The end goal is the depoliticisation ${ }^{7}$ of Standard Afrikaans, described as follows by Prinsloo (1987:182):

Taal en ideologie bly waarskynlik altyd aan mekaar verbind. En tog sou dit as doelwit gestel kon word om 'n taal soos Afrikaans, wat deur 'n landsontwikkelingsproses sterk gepolitiseer geraak het, sover moontlik te depolitiseer. Maar dan gaan dit van die sensitiwiteit en samewerking van almal in die Afrikaanse gemeenskap afhang of die depolitiseringsproses sal werk of nie. 'n Depolitiseringstrewe sal 'n belangrike saambindende strewe kan word in so 'n gevarieerde gemeenskap soos die totale Afrikaanse taalgemeenskap. ${ }^{8}$

This discussion on the so-called "depoliticisation" of the standard language is not unique to Afrikaans. Bourdieu (1991) and others have often indicated that standardisation is a matter of language politics (De Rooij 1987:10). According to Huss and Lindgren (2011:1), it is possible to gain and maintain power through language. In a discussion about Bourdieu's ideas on legitimate language, Thompson (1991:5) indicates that the idealised language (the standard language) is an object constructed by a set of sociohistorical conditions which give it the status

\footnotetext{
${ }^{4}$ A diglossic situation exists when there is a gap between the standard language and the vernacular, resulting in significant differences between the two despite the fact that they are related language forms (Ponelis 1992:7980, 1994:117-118).

5 "Afrikaners" is used here as it was used mainly in the first half of the 20th century, namely as a reference to anybody whose highest loyalty was to South Africa and who allowed Dutch/Afrikaans its rightful place in the country, but mainly referring to white speakers of Afrikaans devoted to the Reformed faith (Giliomee 2004:307).

${ }^{6}$ This term refers to those people classified as "brown" under the apartheid regime. I use this term with some reservation as I am aware of the possible negative or discriminatory connotations that it might have. I do not, however, identify myself with this and similar racial pejoratives.

${ }^{7}$ It is important to note that no language can really be depoliticised. Willemse (2009:2) points out that no language can be without politics and that those who demand a language without values or politics are subtly pushing their own politics. As explained in section 4.2, "depoliticised" rather means "democratic" in this paper.

8 "Language and ideology will probably always remain bound together. And yet the goal could be to depoliticise Afrikaans, a language that had become strongly politicised in the midst of a national development process. But then the success of the depoliticisation will depend upon the sensitivity and cooperation of all members of the Afrikaans community. The pursuit of depoliticisation could also become an important uniting force in a group as varied as the total Afrikaans speech community".
} 
of being the only legitimate or "official" language of a specific speech community. Languages, therefore, do not develop "naturally" - they are formed within definite boundaries and are manipulated in order to serve the interests of a specific group (Alexander 2013:93). This is especially true for standard languages, as Alexander (2013:93-94) explains in the following excerpt:

This is very clear in the case of so-called standard languages, as opposed to nonstandard varieties (dialects, sociolects). The former are invariably the preferred varieties of the ruling class or ruling strata in any given society. They prevail as the norm because of the economic, political-military or cultural-symbolic power of the rulers, not because they are 'natural' in any meaning of the term.

Standard languages, therefore, have a privileged position in society. They prescribe an "ideal form" according to which one should write and speak if one wishes to belong to the "educated" class, while everything outside of the standard is often rejected as an "error" or "dialect". With regard to the so-called "standard language cultures", knowledge of the standard language is not acquired through its use, but rather by teaching and the deliberate study of the grammar and lexicon. It is therefore seen as a cultural yardstick which symbolises the social, educational and often also moral standing of the speaker in society. The standard language has little to do with intelligibility or fluent communication. Rather, it is an elite issue of which the greater part of the population has no part as they cannot express themselves through it and often do not understand it (Deumert 2005:19, Van der Horst 2009:11). Regardless of how one views standard languages, it is clear that these languages discriminate against minorities and marginalised groups. Even in the "enlightened" times in which we live, this discrimination is rife, although done in a more subtle fashion since explicit elitism is no longer tenable (Parakrama 1995:41). Therefore, there can no longer be a uniform standard language since there is no interest in it or a need for it anymore (Stroop 1992:162).

Since 1970, however, the level of interest in the domain of "correct" or "proper" language has gradually decreased (Van der Horst 2009:11). But why has there been a change, or is there a change taking place, in people's perception of the standard language? A few plausible reasons relate especially to the global political changes of the 1980s and 1990s, such as the end of the Cold War and the subsequent major changes in national borders in Eastern and central Europe, the unification of Germany, the end of apartheid in South Africa, the fall of communism, the disintegration of the Soviet Union of Yugoslavia, the opening of borders in Europe, and the development of European political integration (Clyne 1993:11). This democratisation of the world has led to pluralism and multilingualism which have resulted in an ethnic renaissance across the world during which minorities have started developing the democratic ideal of having the right to use their own culture and identity without being subjected to stigmatisation or discrimination. This has led to the nurturing of (linguistic) diversity (Clyne 1993:22, Huss and Lindgren 2011:9, 11). Stroop (1992:162) states that there is therefore no room for a homogenous standard language in a modern society with a high degree of democracy and diverse speech communities. In a society where people can function as equals, a uniform standard language is no longer a goal to be reached; everyone can use their own language form since all language varieties are regarded as equal (Stroop 1992:171).

Another result of globalisation is the flood of immigrants entering wealthier countries, especially in Europe (Stroop 1992:169), which has resulted in a large measure of linguistic 
diversity in previously-monolingual countries. These second-language speakers often represent a significant portion of the speech community and they have an undeniable effect on the standard language in terms of, for example, language transfer or incomplete acquisition of the standard language (Stroop 1992:169).

A further change in society is the tendency, since the 1960s, for people to question all types of rules, including those concerned with language. However, this period of free thought has resulted in the tendency to ignore many rules simply because they were rules. The same effect is found with regard to linguistic rules and norms (Stroop 1992:170). Furthermore, questions have also arisen regarding linguistic ownership, such as "Wie is de baas over de taal?".

A fourth reason is related to the informalisation of society. Informalisation involves the minimising of contrasts in society, extreme behaviour and emotion moving closer together, and the continuum of behaviour, emotion and values becoming narrower than before. The norms upon which people judge each other's behaviour are less rigid and non-normal behaviour is excused on the grounds of external factors and mitigating circumstances. People are no longer bound by a predetermined set of rules, but have the freedom to determine their own rules and norms in a given situation (Stroop 1992:173). According to Stroop (1992:173-174), this informalisation also reflects on the standard language, which he explains as follows:

As far as language is concerned this means that the extremes (say the dialects on the one hand and the homogeneous Standard Language on the other) are disappearing and that the so called Standard Language is changing into a broad spectrum of variations which are all accepted.

Finally, there have been various changes in education, causing a decreased interest in language learning and language rules. Much time is spent nowadays teaching children communication, while little attention is paid to aspects such as idioms, speech, pronunciation, grammar, etc. In many countries, pronunciation and grammar no longer form an important part of the curriculum. There is also a greater tolerance these days for linguistic variation. This tolerance, however, is also a source of great confusion for teachers, who are themselves uncertain about what is "right" and "wrong" in the language. This "problem" is dealt with by simply ignoring it. Consequently, more time is spent on other aspects, such as literature, and therefore language learning falls by the wayside (Stroop 1992:169-170).

Given these worldwide changes in society, Van der Horst $(2009: 6,10)$ is of the opinion that, based on cultural-historical grounds, we can be quite certain that there is a trend towards destandardisation.

\section{Destandardisation: The end of standard language?}

Destandardisation is the result of a liberation movement which causes a decline in the acceptance of old standards (Van Keymeulen 2010:150-151) and causes a highly standardised language to regress to a situation of dialectic diversity (Joseph 1987:174). The question now arises as to what would happen if norms and rules were to lose their authority. What happens if

\footnotetext{
9 "Who is the boss of the language?" This was the topic of a public symposium held in Leiden on 15 June 2013. The symposium was presented by Jaap de Jong and Marc van Oostendorp, both of whom are affiliated with the Leiden University Centre for Linguistics (LUCL) in Leiden, the Netherlands (Carstens 2013).
} 
the boundaries around a language fall away so that the outward delineation becomes diffuse once more and the previously pursued internal homogeneity is no longer pursued? In other words, what happens when the standard language ceases to exist? (Van der Horst 2008:305)

Drosdowski (1988, in Van der Horst 2008:303) asks the following question with regard to standard language: "Ist unsere Sprache noch zu retten?"10. Van der Horst (2008:303) answers this with an unambiguous "no" and believes that we will soon have to make do without a standard language. In a new destandardisation situation, defining boundaries between separate languages would become more diffuse while internal variation would become more acceptable. The language continuum would therefore be repaired. This does not mean that a single language would eventually develop or that all language forms would now be accepted, but merely that there would be gradually fewer boundaries within a language continuum and that different language forms would be accepted in parallel and would compete with one another (Van der Horst 2008:311, 2009:11). According to Van Der Horst (2008:312), it would also mean that there would no longer be one privileged norm for all sorts of written language. The language is relieved of its sanction or license to function as before; in other words, it is no longer the privileged language form (Kotzé 2009:1, 2010:154).

Does this mean that we will have to make do without a standard language in the future? Odendal (1992:21) points out that a language's chances of survival, as well as further development and revival, are strengthened if the language has a standardised variety. The need for standard languages in the lives of modern communities is also significant. Webb (2010:210) emphasises the importance of a fully standardised language for speech communities. Standard languages determine the norms for language use in public domains and serve as varieties for communicating with government, state administration and within the legal system (Webb 2010:197). The standard variety therefore serves as a broader, supradialectical means of communication or a kind of lingua franca (De Villiers 1985:42). It also serves as a medium of written language in that it is the variety in which official documentation can be distributed (De Villiers 1985:51, Webb 2010:197). Standard languages are the varieties used for high-level professional activities as well as participation in the political, economical and educational spheres of a speech community. As a vital variety for intellectual development, the standard language plays an extremely important role in technology and education. As a medium of instruction, this variety mediates the acquisition of knowledge, conceptual development and skills development. It is also the variety through which learners must demonstrate their knowledge, insight and cognitive ability as it provides the norms for the assessment of learners' achievement (De Villiers 1985:47, Webb 2010:197). Furthermore, it is the variety used in public discourse, publication and the maintenance of a reading culture, as well as being the language of the media and translation (De Villiers 1985:43, Webb 2010:197). Lastly, the standard variety also has an ideologisation function. Its symbolic value is most significant here as the standard language is a symbol of national unity, solidarity, social identity and prestige (De Villiers 1985:45, Webb 2010:197).

According to Agamben (in Krog 2004:5), all languages are in situations of tension. On the one hand, there is the pursuit of innovation and transformation, mostly by means of disregarding existing norms; on the other hand, there is stability and maintenance, mostly in the form of grammatical norms (Agamben, in Krog 2004:5). Standardisation and destandardisation are

10 "Can our language still be saved?" 
indicative of this tension in language and have resulted in the recent calls for the restandardisation of languages.

\section{What does restandardisation entail?}

Although discussions on restandardisation are prevalent in other parts of the world (cf. e.g. Lloshi (2006) and Mantho (2009) concerning the Albanian standard language since the democratisation of Albania), the concept of 'restandardisation' seldom features in international literature. The term features more often in South African sociolinguistics, especially with regard to Afrikaans and South African English. Definitions for restandardisation, however, are quite vague or even contradictory, since it seems to have various meanings for different sociolinguists. In the following section, I will elaborate on my understanding of "restandardisation" by identifying the aspects which, in my view, form a part of it, and by discussing other researchers' definitions of the concept in order to formulate an unambiguous definition of the term.

\subsection{Restandardisation as language planning process}

During restandardisation, according to Kotzé (2009:1, 2010:154, 2011:36), an alternate macroselection ${ }^{11}$ forms the basis from which the redefinition of a new standard is undertaken and new norms are made applicable, or other functions are allocated to the language. For Kotzé (2009:1, 2010:154, 2011:36), the emphasis falls on standardisation (in other words, restandardisation as "standardising again"), by which restandardisation represents a similar process to standardisation but involves a different set of norms or language functions. This link with standardisation implies that restandardisation can be seen as a language planning process.

Just as there is room for language planning if a language situation is deemed to be undesirable for some or other reason (Haugen 1972b:161), restandardisation will be found where there is a need for it in a language because the current situation of the standard is no longer deemed suitable by the speakers. For Schiffman (1998:362-363), who investigated the emergence of a new standard form of Tamil called Standard Spoken Tamil (SST), restandardisation in a language takes place when a newer version of the language, with its own spoken form, attempts to challenge or take over some of the usage domains of an older, prestigious, literary language which no longer succeeds in being a successful medium of verbal communication. Schiffman, however, does not provide any suggestions as to why a language would cease to be successful in this regard. Van de Rheede (1985:36-37) indicates that every language variety is suitable as a means of communication for its speakers since each variety contains the potential for expansion and change to suit the needs of its speakers. One can therefore assume that the reasons as to why a language would no longer succeed in being a medium of verbal communication, are not linguistic in nature, i.e. it is not some or other shortcoming in the language itself that would necessitate restandardisation. Restandardisation, like language planning in general for Haugen (1983:286), is a response to a social problem or to changes experienced by a specific social group rather than being a response to linguistic deficiencies or requirements (Wade 1996:62). Furthermore, Cooper (1989:154), who views restandardisation

\footnotetext{
${ }^{11}$ Macroselection is the selection of a specific language or language variety, a so-called "matrix variety", which is chosen to fulfil certain needs in a given society. The process of macroselection takes place when deciding which language variety is to become the standard (Deumert 2000:388, 2008; Van Keymeulen 2010:141; Kotzé 2011:36).
} 
as a component of the corpus planning ${ }^{12}$ category he calls "renovation", indicates that restandardisation is not motivated by purely communicative needs but rather by non-linguistic goals. Restandardisation is therefore a sociopolitical action, as stated by Johl (2002:173).

Bruthiaux (2006:32) views restandardisation as a type of natural language change in the direction of internal linguistic norms which is steered by means of official measures and supported by sanction. Furthermore, he views restandardisation as having minimal input from language planners. Wade (1996:4) also supports the "natural" nature of restandardisation. However, if restandardisation is viewed as a language planning process, the "natural" element becomes invalid. According to Thorburn (1971:254), planning implies a conscious choice between alternative solutions to a problem. In language planning, this choice represents an attempt to steer the development of a language in a specific direction (Haugen 1959:8, 1972a:133) which makes it a deliberate action (Reagan 2002:420). In addition, Deumert (2000:384) supports the deliberate nature of language planning by defining the concept as "deliberate, conscious, and future-oriented activities aimed at influencing the linguistic repertoire and behavior of speech communities" (Deumert 2001). Therefore, if one is to regard restandardisation as a language planning process, the implication is that this planning process is conscious (Wade 1996:62).

Another aspect of language planning, noted in Deumert's aforementioned definition, is that it is not aimed solely at influencing the language as such, but also at influencing the linguistic behaviour of the speakers. Weinstein (1990:5) elaborates on this by describing language planning as a conscious choice between language form and language function. Cooper (1989:183) also emphasises the deliberate nature of language planning, which influences every aspect of language, when he defines language planning as "deliberate efforts to influence the behavior of others with respect to the acquisition, structure, or functional allocation of their language codes". Language planning, and subsequently also restandardisation, is therefore aimed at changing or influencing the language form, language functions and linguistic behaviour of speakers. From this, it follows that restandardisation includes different language planning dimensions.

Kloss (1969:81) distinguishes between two basic language planning dimensions, namely corpus planning and status planning. Corpus planning modifies the language itself which means that specific institutions, individuals or groups attempt to change the corpus of a language by introducing new technical terminology, changing spelling, importing a new writing system, etc. (Kloss 1969:81). Corpus planning thus includes planning activities concerned with the form or internal structure of language, for example, the orthography, writing system and lexicon, and grammar such as morphology, syntax and phonology (Du Plessis 2000:149, Deumert 2000:385, Fishman 2004:79). It is clear that Wade (1996:4) views corpus planning as a component of restandardisation, judging by his definition of the latter as the reselection of variants (whether phonological, syntactic or pragmatic in nature) from other varieties of the given language and the redefinition of the language model based on these.

Status planning, on the other hand, is concerned with whether the status of a language is satisfactory and whether it needs to be raised or lowered (Kloss 1969:81). This refers to all attempts to change the status of a language or language variety in society by altering its use and

${ }^{12}$ This concept is defined later in this section. 
functions (Deumert 2000:385, Du Plessis 2000:150-151). Furthermore, it refers to deliberate attempts to influence the allocation of language functions with regard to the languages or varieties of a community (Cooper 1989:99). According to Wade (1996:12), restandardisation would have a direct effect on the social status of the non-standard varieties of a language.

Prestige planning is the third language planning dimension and was first introduced by Haarmann (1990). This dimension aims to create a positive attitude towards corpus and status planning in the minds of the speakers of a language - a vital requirement for the long-term success of language planning activities (Deumert 2000:387, 2001). While corpus and status planning are productive activities, prestige planning has an acceptance or value function which affects the manner in which corpus and status planning are received and accepted by the speech community (Kaplan and Baldauf 1997:50). Prestige planning is aimed at positively influencing the language attitudes ${ }^{13}$ of the members of the speech community and, eventually, their linguistic behaviour. This is especially vital where a language had previously been limited to lower functions, as in the case of diglossia ${ }^{14}$ (Deumert 2000:387, 2001). According to Bruthiaux (2006:32), when a language is restandardised, measures are also designed and implemented to steer or change the language in such a way that the internal norms of the language increasingly affect people's linguistic behaviour. This is also reflected in what Wade (1996:12) calls "active restandardisation". Active restandardisation takes place when speakers of the standard language include the new qualities or uses in their active language use; in other words, their linguistic behaviour reflects the changes which have been made to the standard language (Wade 1996:13).

Deumert (2000:385) views standardisation as the most important component of language planning. According to Romaine (2007:687), standardisation can be viewed as a language planning activity, as it is concerned with attempts to change certain aspects of the form and usage of language. Haugen (1972a:133) also emphasises the importance of standardisation in language planning when he describes the latter as the activity by which a normative orthography, grammar and dictionary are developed to serve as a guide for the speakers and authors in a nonhomogenous speech community. Haugen's (1972c:287) definition of language planning below suggests that he almost equates language planning with standardisation:

As I define it, the term LP [language planning] includes the normative work of language academies and committees, all forms of what is commonly known as language cultivation [...] and all proposals for language reform or standardization.

Therefore, Haugen's language planning model has been used extensively over the years as a descriptive framework for standardisation as a language planning process. Many language planners are even of the opinion that the different stages or phases of Haugen's model should, to some extent, be present in a language before that language could be considered standardised (Van der Wal 1995:1). If one views restandardisation, like standardisation, as a language planning process, it would imply that Haugen's four stages of language planning (1966:18, 1983:270; cf. also Deumert 2001 and Ricento 2007:219) can also be applied to restandardisation. These four stages are:

\footnotetext{
${ }^{13}$ Language attitudes refer to the feelings speakers have about their own language and/or the language of others.

${ }^{14} \mathrm{Cf}$. fn. 4 for a definition of this concept.
} 
1. Selection (of a language variety or varieties to serve as (a) basis for the norm);

2. Codification (of the selected form);

3. Implementation (of the selected and codified language by the entire community), and

4. Elaboration and modernisation (of the language by expanding the lexicon and other aspects needed to provide for the communicative needs of the community).

Although these four steps indicate a seemingly logical progression, they need not be sequential. They can also take place simultaneously and in cycles. Selection and codification are concerned with the form of the language, while implementation and elaboration are concerned with its function. Selection and implementation are concerned with the social aspect of language and are therefore external to language itself. In contrast, codification and elaboration are primarily linguistic in nature and are therefore internal to language itself (Haugen 1983:270). This distinction corresponds to Kloss's categories of status and corpus planning (Haugen 1983:272; cf. also Kaplan and Baldauf 1997:30). This exposition is known as Haugen's "classical" language planning model (Haugen 1983:275) and can be represented in tabular form as demonstrated in Table 1.

Table 1. Haugen's (1983) language planning model

\begin{tabular}{lcl}
\hline & Form (policy planning) & Function (language cultivation) \\
\hline $\begin{array}{l}\text { Society } \\
\text { (status planning) }\end{array}$ & $\begin{array}{l}\text { 1. Selection } \\
\text { (decision procedures) } \\
\text { a. problem identification } \\
\text { b. allocation of norms }\end{array}$ & $\begin{array}{l}\text { 3. Implementation } \\
\text { (educational spread) } \\
\text { a. correction procedures } \\
\text { b. evaluation }\end{array}$ \\
$\begin{array}{ll}\text { Language } \\
\text { (corpus planning) }\end{array}$ & $\begin{array}{l}\text { 2. Codification } \\
\text { (standardisation procedures) } \\
\text { a. graphisation } \\
\text { b. grammatication } \\
\text { c. lexication }\end{array}$ & $\begin{array}{l}\text { (functional development) } \\
\text { a. terminological modernization } \\
\text { b. stylistic development }\end{array}$ \\
& & \\
\hline
\end{tabular}

Selection is required when a language problem has been identified (Haugen 1983:270), after which norms must be allocated. Haugen (1968:267) views norm selection as the first problem of standardisation. Norm selection comprises the selection and promotion of one or several specific language forms as norms (Deumert 2000:388, Van Keymeulen 2010:141). Codification comprises the formalisation of a linguistic standard or norm for the chosen language variety (Kaplan and Baldauf 1997:39, Deumert 2000:389). This can be divided into three stages, namely graphisation (the development of an alphabet), grammatication (decision-making regarding the rules/norms for grammar) and lexication (the identification of the lexicon) (Haugen 1983:271, Deumert 2000:389). Implementation refers to the sociopolitical realisation of the decisions made during the stages of selection and codification. This includes the promotion, gradual spread, establishment, acceptance and use or application of the new selected and codified norm by the speech community across all functions (Haugen 1983:272; Deumert 2000:392, 2001; Deumert and Vandenbussche 2003:7; Kotzé 2011:36). The specific measures followed by language planners in order to implement this social aspect of language planning are known as "correction procedures" (Haugen 1983:274, Kaplan and Baldauf 1997:36). It is not enough to merely institute strategies for changing a particular linguistic situation. In 
addition, it is just as important to monitor the success of the strategies and the progress towards the implementation of the language form by means of a process of evaluation (Haugen 1983:274, Kaplan and Baldauf 1997:37). Elaboration (or modernisation) is the constant terminological, orthographical, grammatical and stylistic modernisation and development which a codified language has to undergo in order to continue to meet the ongoing communicative needs of the speakers in terms of technology and modern life (Haugen 1983:273, Deumert 2000:392, Deumert and Vandenbussche 2003:7).

\subsection{Restandardisation as an instrument for democratisation}

Webb (1997:227) is of the opinion that language should become a resource in the process of democratisation. Democratisation comprises the opposition to the stigmatisation of nonstandard varieties and the negative consequences for the speakers of these varieties, such as linguistic uncertainty, negative self-image and scholastic failure (Swanepoel 1995:69). According to Webb (1997:228), the language should not become a basis for discrimination and exploitation, as is the case with ideological language planning. Ideological language planning is aimed at establishing specific views, beliefs and patterns of behaviour in order to serve the interests of the dominant group or a particular social order, to effect control and dominance, or to create unequal relationships where the Other is posited as secondary and inferior and is therefore kept in a submissive position. Consequently, most standard languages are a result of ideological language planning (cf. section 2). In contrast, Webb (2006:152) describes normative language planning as comprising the formation of action plans for the development, implementation and evaluation of language policies based on the principles of freedom, equality, democracy and empowerment. In essence, normative language planning is aimed at serving the interests of the speech community in its entirety, but specifically supports the struggle of oppressed groups against domination and oppression. The normative approach to language planning supports those struggling against inequality, injustice and oppression and endorses the struggle for liberation and the creation of a free, fair and equal social order (Webb 2006:152). According to Johl (2002:173), the term "restandardisation" is mentioned increasingly where it concerns the restitution of linguistic injustices and the empowerment of disadvantaged speakers. Restandardisation therefore represents a normative approach to language planning which implies that the standard language would have to lose its ideological nature (with all the subsequent negative implications) through this process. In this normative approach to language planning, the standard language would be employed as an instrument of reconciliation in the speech community by serving the interests of all the speakers and especially those who were previously marginalised and oppressed.

Democratisation entails the emancipation of language, which refers to the changing of hierarchical power structures in order to set up a new democratic structure. Furthermore, emancipation politics is concerned with the elimination of the domination of one group by another so that justice, equality and participation can be possible for all. Against this background, language emancipation can be defined as the process through which the subordinate position of dominated languages or varieties can be improved upon, through political attempts and language planning, by breaking down negative perceptions of these dominated languages or varieties (Huss and Lindgren 2011:1-3). An important aspect of language emancipation is therefore the eradication of the negative stigma attached to dominated varieties as well as the negative attitudes towards non-standard varieties (Webb 1997:228, Huss and Lindgren 2011:7). This resounds with what Wade (1996:12) calls "passive restandardisation", 
which entails a broadening of what speakers perceive to be acceptable language use in order to include varieties other than just the narrowly defined standard language. Speakers therefore have a more inclusive view of what exactly constitutes the standard language (Wade 1996:1213). Wade (1996:13) states that passive restandardisation is a vital prerequisite for active restandardisation ${ }^{15}$; in other words, the language attitudes that speakers have towards other varieties first have to change before the changes brought about in the standard language, through the process of restandardisation, will have an effect on speakers' linguistic behaviour. This can be brought about by using the non-standard varieties in different official public domains in order to raise the statuses of the former so that they can be viewed as valuable resources for a modern, democratic society (Huss and Lindgren 2011:2-3, 7-8).

According to Wade $(1996: 10,54)$, if language purism and standardisation have the goal of excluding certain groups of people, restandardisation has the opposite goal in that it broadens the limits of acceptability. Webb (2000:62) states that language teachers should make learners aware of the equal value of all language varieties and of the undeniable part played by all speakers in the genesis and survival of the language, while also making them aware that nonstandard speakers do not have a cultural or cognitive deficit. This implies, for example, that teachers should be more tolerant towards the use of non-standard varieties by learners (Swanepoel 1995:69). If a more relaxed approach towards standardisation is followed, the standard language would become the servant of the people, not its master (Vikør 1989:57). Furthermore, the language of teaching should reflect the heterogeneous sociocultural reality of the language (Webb 1997:227-228). According to Van Rensburg (1984:189), if the study of a language and its varieties were to form a part of syllabi, non-standard languages would obtain a higher status over time and therefore contribute more easily and more spontaneously to the standard. This process would reflect the democratisation of society (Wade 1996:10), something which is currently lacking in standard languages (cf. section 2).

Stander and Jenkinson (1993:36; cf. also Van Rensburg 1992:184) are of the opinion that a democratic linguistic dispensation can be promoted by expanding the standard variety, thereby lessening the differences between the different varieties. In the same vein, Parakrama (1995:42) states that linguists should try to broaden the standard in order to include other varieties in written and spoken language, thereby opposing linguistic discrimination. This relates to Egbokhare's (2002:71) concept of 'harmonisation'. Egbokhare (2002:71) describes harmonisation and the unification of languages, in the context of Africa's Bantu languages ${ }^{16}$, as an attempt to reach back to a time before the "invention" of linguistic diversity in Africa. Various researchers, such as Anderson (1983) and Ranger (1989), have indicated that many of the so-called Bantu "languages" are in fact dialects or varieties of the same languages and that many of the distinct languages are rather creations or "imagined communities" (Anderson 1983). Ranger (1989:127) elaborates upon this situation as follows:

\footnotetext{
${ }^{15} \mathrm{Cf}$. section 4.1 for a definition of this concept.

${ }^{16}$ The term "Bantu" was used in racist and discriminatory policies in apartheid South Africa. I am therefore aware of the possible negative or discriminatory connotations of this word as an ethnic designation. In this paper, however, the term is used merely as a linguistic classification in order to distinguish itself from other African languages. The term "Bantu" means "people" and refers to the largest language group in the Niger-Congo family. The Bantu languages cover a third of Africa, beginning at the border between Cameroon and Nigeria, moving through the equatorial zone to the Kenyan coast and then southwards to the Cape. The Bantu languages spoken in South Africa today include Sepedi, Sesotho, isiNdebele, Siswati, Xitsonga, Setswana, Tshivenda, isiXhosa and isiZulu (Herbert and Bailey 2002:50-54, 74; Williamson and Blench 2000:11-14).
} 
Missionary linguists created discrete dialect zones by developing written languages centred upon a number of widely scattered bases. [...] Differences were exaggerated, obscuring the actual gradualism and homogeneity of the real situation.

The different Bantu languages, as they exist in many parts of Africa today, are therefore mostly a product of Africa's colonial history and are not a true reflection of the linguistic reality. It is from this situation that the idea of harmonisation has emerged - the idea that languages with a historical connection and strong linguistic similarities can once again be united or amalgamated to form an overarching standard (cf. Makoni 1998:157-160, 163-164; Msimang 1998:169-171; Simango 2002:63-65).

According to Msimang (1998:165; cf. also Nakin 2002:244), "harmonisation" is used synonymously with "unification" and comprises the amalgamation of a number of varieties belonging to the same language group in order to form one common language. In doing so, variant forms between varieties are neutralised or harmonised in the unified language (Msimang 1998:165, Nakin 2002:244). This occurs when forms are used which are common to the different varieties and, where no common forms exist, using forms from the dominant language form or the former standard (Lestrade 1935, in Msimang 1998:165). Msimang (1998:166) views this as democratic standardisation, since harmonisation involves the unification of all the varieties of a language and raising their statuses to that of the standard. I suggest that Msimang's (1998:165) link between harmonisation and standardisation can also be extended to restandardisation. With restandardisation, the focus falls on the spoken varieties of a language, with implications for the way in which the spoken variety and the standard are to be brought closer together (Johl 2002:173).

Wade (1996:11) and Johl (2002:173-174) distinguish between reformist and radical restandardisation based on the way in which different varieties are united in the standard. In the reformist approach, restandardisation mainly influences the existing standard (Wade 1996:11). Specifically, this approach is concerned with structural changes to the standard for the sake of reflecting the changing relationship between the different speech communities (Johl 2002:173). The boundaries of what is (not) defined as a part of the standard are significantly expanded in order to incorporate elements of other varieties of the language. The varieties, from which elements are added to the standard, continue to exist separately as they do not have the status of standard language (Wade 1996:11). Wade (1996:11) views this type of restandardisation as superficial since the standard would still be "owned" by the elite. This is because the only change that has occurred has been to its social meaning, causing it to no longer be defined as a product of the ruling elite (Wade 1996:11). On the other hand, radical restandardisation means changing the varietal basis of the standard language (Johl 2002:174). This type of restandardisation would therefore result in an acrolectic standard language of the former nonstandard varieties along with the existing standard language. It could even result in the eventual replacement of the existing standard with the new standard. Radical restandardisation can be led by speakers of the non-standard varieties, giving them "ownership" of the new, emerging standard (Wade 1996:11). The chances of strong resistance from those who subscribe to the existing standard are obviously much greater in the case of radical restandardisation than in that of reformist standardisation (Johl 2002:174). Therefore, it is my view that radical restandardisation is unfeasible. People are generally slow to adopt change, even more so when that change is too fundamental or drastic. By retaining the positive aspects of the existing 
standard, there is a greater chance that the speech community would eventually accept the proposed changes to the standard and start using the new standard. In my view, it would also be impractical and short-sighted to eliminate the existing standard as a whole. As Kotzé (2011:3) notes, there is no need to reinvent the wheel of (re-)standardisation and learning compulsively from one's own mistakes, as there is much to learn from the experience of others.

The democratisation of the standard (which is the aim of restandardisation) also entails that language norms have to be determined in a democratic manner (De Villiers 1985:37, 52). According to De Villiers (1985:37), rules which are not determined democratically probably do not form a valid description of the language's system because they are actually contradictory to how the language is really used by the speech community. This can cause the standard to be viewed as artificial (Joseph 1981:180). The variety within the particular language must be included in its totality in investigations and planning of the language - not solely the regimented forms, but also all the different varieties (Senekal 1984:213). Linguistic rules must be based on how language is actually used in most cases, with the norms therefore being based on empirical description (Joseph 1981:179). This implies that the standard language must be based on a descriptive analysis of the speakers' linguistic behaviour (De Villiers 1985:51).

Furthermore, the democratisation of a language also requires the input of the entire speech community in the infrastructure of the language (Sonn 1990:5-6; cf. also Stander and Jenkinson 1993:36). Webb (2005:41), Bruthiaux (2006:43) and Kotzé (2011:32-33) indicate that standardisation is essentially a top-down process and that changes to the standard therefore tend to take place by means of top-down institutional involvement; in other words, authoritative institutions, like government, and official language planning institutions, like language academies, initiate and execute language planning. However, Webb (2006:159) warns that language planning cannot only be a top-down process as this approach is seldom successful. Meaningful cooperation from the speech community is of vital importance and restandardisation is impossible without bottom-up support (Webb 2006:159). All mother tongue speakers must have equal input into the standard, on both formal and informal levels. This ensures a democratic linguistic dispensation in which the language would be standardised from a broader base of linguistic variation (Stander and Jenkinson 1993:30). Therefore, it is vital that restandardisation should incorporate both a top-down and bottom-up approach (Webb 2005:41).

For Johl (2002:176), the restandardisation strategy she calls "harmonisation"17 represents a bottom-up process. Johl (2002:176) describes harmonisation as the "opening up" of the standardisation process so that the language can follow its natural course, the involvement of all roleplayers on a fair and equal basis, a "relaxation" of the standard, tolerance towards differences, the nurturing of diversity and the handover of authority to the speech community itself. People at grass-roots level and non-governmental organisations therefore become involved in the process (Johl 2002:175). Webb (2005:41) also suggests that key roleplayers, such as teachers, should be involved in the process as a bottom-up approach requires the support and commitment from both the public and the private sectors (Webb 2006:159). The interests of the speech community must be properly taken into account and therefore restandardisation should also be aimed at the national, regional and local needs of the speech community (Webb

\footnotetext{
${ }^{17}$ This definition of harmonisation should not be confused with the more generally accepted definition which is especially prevalent in the context of language planning for the Bantu languages, as defined and elaborated upon earlier in this section.
} 
2005:41, 2006:159). However, it should be borne in mind that speech communities are often unaware of their linguistic needs as they are governed and motivated by their immediate wants and are usually unaware of the long-term implications of their linguistic choices (Webb 2006:159). Hence, the required information must be made available to the speech community in order to ensure their cooperation (Webb 2006:159). Eastman (1992:108) suggests that this bottom-up approach can be adopted by working specifically with language attitudes. Therefore, in restandardisation, special attention needs to be paid to prestige planning (cf. section 4.1). This also entails that language forms which had previously been limited to informal domains and therefore had little prestige, should be applied increasingly in formal domains (Johl 2002:175).

\section{Restandardisation: A definition}

Based on the abovementioned considerations, I propose the following definition for restandardisation:

Restandardisation is deliberate language planning from above and from below which is aimed at revising the form and function of a standard language and influencing the linguistic behaviour of a speech community in order to create a democratic standard. Furthermore, restandardisation comprises the correction of some or other social injustice in the speech community by standardising the language from a broader varietal base, thereby making the standard language more inclusive in order to empower all speakers.

From this definition, it is clear that restandardisation can be viewed as democratising language planning ${ }^{18}$, or language planning for the purpose of creating a democratic linguistic dispensation.

\section{Conclusion}

In this paper, restandardisation has been defined as democratising language planning by indicating the degree to which restandardisation differs from standardisation and destandardisation, while also engaging both of these processes. Literature on restandardisation, standardisation, destandardisation, and other aspects of language planning, has been discussed in order to identify the various defining characteristics of restandardisation. This has been carried out with the view that standard languages are no longer capable of serving speech communities effectively. This is because these standard languages do not reflect the democratic values which are increasingly held and which are motivated by a number of global changes that have taken place over the past few decades.

This working definition will be tested in forthcoming papers by applying it with a view to describing the restandardisation of Afrikaans, as well as providing a model for restandardisation. Other researchers are encouraged to test this definition by applying it to other languages, for example, South African English, the Bantu languages, or other Germanic or international languages. Possible modifications or elaborations upon this definition based on such applications would be welcomed.

\footnotetext{
${ }^{18}$ Note that democratising language planning does not represent a separate type or classification of language planning, but rather denotes any language planning activities which aim to create a democratic linguistic dispensation in which all speakers are represented and have equal input.
} 


\section{References}

Alexander, N. 1990. Afrikaans en taal-onderrig in 'n vry Suid-Afrika. Die Suid-Afrikaan 29: 38-39.

Alexander, N. 2013. Thoughts on the new South Africa. Johannesburg: Jacana.

Anderson, B. 1983. Imagined communities: Reflections on the origin and spread of nationalism. London: Verso.

Bourdieu, P. 1991. The production and reproduction of legitimate language. In J.B. Thompson (ed.) Language and symbolic power. Cambridge: Polity Press. pp. 43-65.

Bruthiaux, P. 2006. Restandardizing localized Englishes: Aspirations and limitations. International Journal of the Sociology of Language 177: 31-49.

Carstens, W.A.M. 16 July 2013. Wie is de baas over de taal? Available online: http://nederl.blogspot.com/2013/07/wie-is-de-baas-over-de-taal_16.html\#more (Accessed 19 July 2013).

Clyne, M. 1993. The German language after unification: Adapting assumptions and methodologies to the "new world order". International Journal of the Sociology of Language 100/101: 11-27.

Cooper, R. 1989. Language planning and social change. Cambridge: Cambridge University Press.

Davids, A. 1987. The role of Afrikaans in the history of the Cape Muslim community. In H. du Plessis and T. du Plessis (eds.) Afrikaans en taalpolitiek: 15 opstelle. Pretoria: HAUM. pp. 3759.

De Rooij, J. 1987. Inleiding. In J. de Rooij (ed.) Variatie en norm in de standaardtaal. Amsterdam: P.J. Meertens-Instituut voor Dialectologie, Volkskunde en Naamkunde. pp. 7-11.

Deumert, A. 2000. Language planning and policy. In R. Mesthrie, J. Swann, A. Deumert and W.L. Leap (eds.) Introducing sociolinguistics. Edinburgh: Edinburgh University Press. pp. 384418.

Deumert, A. 2001. Language planning: Models. In R. Mesthrie and R.E. Asher (eds.) Concise encyclopedia of sociolinguistics. Oxford: Elsevier Science \& Technology. Available online: http://www.credoreference.com.ez.sun.ac.za/entry.do?id=8024085 (Accessed 28 July 2013).

Deumert, A. 2005. The shape of the standard - Reflections on post-colonial standard languages, with special attention to South Africa. In V. Webb, A. Deumert and B. Lepota (eds.) The standardisation of African languages in South Africa. Pretoria: PanSALB. pp. 35-42.

Deumert, A. and W. Vandenbussche. 2003. Standard languages. Taxonomies and histories. In A. Deumert and W. Vandenbussche (eds.) Germanic standardizations: Past to present. Amsterdam/Philadelphia: John Benjamins. pp. 1-14. 
De Villiers, A. 1985. Standaardafrikaans en Omgangsafrikaans in Pretoria. Unpublished MA thesis. Pretoria: University of Pretoria.

Du Plessis, H. 2000. Taalbeplanning. In T. du Plessis and A. van Gensen (eds.) Taal en stryd 1989-1999: Gedenkbundel. Pretoria: Van Schaik. pp. 142-162.

Eastman, C.M. 1992. Sociolinguistics in Africa: Language planning. In R.K. Herbert (ed.) Language and society in Africa. Johannesburg: Witwatersrand University Press. pp. 95-114.

Egbokhare, F.O. 2002. A proposal for the unification and harmonization of Edoid languages. In F.O. Egbokhare and S.O. Oyetade (eds.) Harmonization and standardization of Nigerian languages. Cape Town: CASAS. pp. 70-86.

Fishman, J.A. 2004. Ethnicity and supra-ethnicity in corpus planning: The hidden status agenda in corpus planning. Nations and Nationalism 10(1/2): 79-94.

Giliomee, H.B. 2004. Die Afrikaners - 'n Biografie. Cape Town: Tafelberg.

Haarmann, H. 1990. Language planning in the light of a general theory of language: A methodological framework. International Journal of the Sociology of Language 86: 103-126.

Haugen, E. 1959. Planning for a standard language in modern Norway. Anthropological Linguistics 1(3): 8-21.

Haugen, E. 1966. Language conflict and language planning: The case of modern Norwegian. Cambridge, Massachusetts: Harvard University Press.

Haugen, E. 1968. The Scandinavian languages as cultural artifacts. In J.A. Fishman, C.A. Ferguson and J. Das Gupta (eds.) Language problems of developing nations. New York: John Wiley and Sons. pp. 267-284.

Haugen, E. 1972a. Language planning in modern Norway. In A.S. Dil (ed.) The ecology of language. Stanford: Stanford University Press. pp. 133-147.

Haugen, E. 1972b. Linguistics and language planning. In A.S. Dil (ed.) The ecology of language. Stanford: Stanford University Press. pp. 159-190.

Haugen, E. 1972c. Language planning, theory and practice. In A.S. Dil (ed.) The ecology of language. Stanford: Stanford University Press. pp. 287-298.

Haugen, E. 1983. The implementation of corpus planning: Theory and practice. In J. Cobarrubias and J.A. Fishman (eds.) Progress in language planning. Berlin: Mouton Publishers. pp. 269-289.

Herbert, R.K. and R. Bailey. 2002. The Bantu languages: Sociohistorical perspectives. In R. Mesthrie (ed.) Language in South Africa. Cambridge: Cambridge University Press. pp. 50-78. 
Huss, L. and A.-R. Lindgren. 2011. Introduction: Defining language emancipation. International Journal of the Sociology of Language 209: 1-15.

Johl, C. 2002. (Re-)standardisation, harmonisation and Afrikaans. A few cautionary notes. In K.K. Prah (ed.) Speaking in unison: The harmonisation and standardisation of Southern African languages. Cape Town: CASAS. pp. 161-176.

Joseph, J.E. 1981. The standard language: Theory, dogma and sociocultural reality. Unpublished $\mathrm{PhD}$ dissertation. Michigan: University of Michigan.

Joseph, J.E. 1987. Eloquence and power: The rise of language standards and standard languages. Oxford: Blackwell.

Kaplan, R.B. and R.B. Baldauf. 1997. Language planning. From practice to theory. Clevedon: Multilingual Matters.

Kloss, H. 1969. Research possibilities on group bilingualism: A report. Quebec: International Centre for Research on Bilingualism.

Kotzé, E. 2009. Hoe standaard kan 'n taal wees? Perspektiewe op die teenstrydighede van Afrikaans. Paper presented at the "Roots" conference, 22-23 September 2009, University of the Western Cape, Bellville.

Kotzé, E. 2010. Destandaardisasie en herstandaardisasie: Gelyklopende prosesse in die nuwe Suid-Afrika? In M. van der Wal and E. Francken (eds.) Standaardtalen in beweging. Amsterdam: Stichting Neerlandistiek VU. pp. 153-169.

Kotzé, E. 2011. Standaardisering en "mainstreaming" - die kloutjie by die oor. In K.K. Prah (ed.) Veelkantiger Afrikaans: Streeksvariëteite in die standaardvorming. Cape Town: CASAS. pp. 30-43.

Krog, A. 19 September 2004. Só maak die taaldebat wel saak. Rapport. p. 5.

Lloshi, X. 2006. Standard Albanian - Linguistic controversy in post-Communist Albania. International Journal of the Sociology of Language 178: 93-101.

Makoni, S. 1998. In the beginning was the missionaries' word. The European invention of an African language: The case of Shona in Zimbabwe. In K.K. Prah (ed.) Between distinction \& extinction. The harmonisation and standardisation of African languages. Johannesburg: Witwatersrand University Press. pp. 157-164.

Mantho, E. 2009. The present day situation on Standard Albanian and the theory of argumentation about it. Investigationes Linguisticae 18: 72-79.

Msimang, T. 1998. The nature and history of harmonisation of South African languages. In K.K. Prah (ed.) Between distinction \& extinction. The harmonisation and standardisation of African languages. Johannesburg: Witwatersrand University Press. pp. 165-172. 
Nakin, R. 2002. Harmonisation and standardisation: The Sotho-Tswana language group. In K.K. Prah (ed.) Speaking in unison: The harmonisation and standardisation of Southern African languages. Cape Town: CASAS. pp. 237-247.

Odendaal, B.G. 2012. Die herstandaardisering van Afrikaans: 'n Praktiese benadering met die AWS as gevallestudie. Unpublished PhD dissertation. Stellenbosch: Stellenbosch University.

Odendal, F.F. 1992. Standaardafrikaans en Statusafrikaans. Aambeeld 20(1): 18-23.

Parakrama, A. 1995. De-hegemonizing language standards: Learning from (post)colonial Englishes about 'English'. London/New York: Macmillan Press/St. Martin's Press.

Ponelis, F.A. 1984. Afrikaans binne meertalige verband. In K.P. Prinsloo and M.C.J. van Rensburg (eds.) Afrikaans: Stand, taak, toekoms. Pretoria: HAUM. pp. 30-42.

Ponelis, F.A. 1987. Die eenheid van die Afrikaanse taalgemeenskap. In H. du Plessis and T. du Plessis (eds.) Afrikaans en taalpolitiek: 15 opstelle. Pretoria: HAUM. pp. 3-15.

Ponelis, F.A. 1992. Standaardafrikaans in oorgang. In V.N. Webb (ed.) Afrikaans ná apartheid. Pretoria: J.L. van Schaik. pp. 69-89.

Ponelis, F.A. 1994. Standaardafrikaans in oorgang. In V. February (ed.) Taal en identiteit: Afrikaans en Nederlands. Cape Town: Tafelberg. pp. 106-128.

Ponelis, F.A. 1998. Standaardafrikaans en die Afrikaanse taalfamilie. University of Stellenbosch Annals 1: 1-80.

Prinsloo, K.P. 1987. Afrikaans in oorgang. In H. du Plessis and T. du Plessis (eds.) Afrikaans en taalpolitiek: 15 opstelle. Pretoria: HAUM. pp. 177-183.

Ranger, T. 1989. Missionaries, migrants and the Manyika: The invention of ethnicity in Zimbabwe. In L. Vail (ed.) The creation of tribalism in Southern Africa. Berkeley: University of California Press. pp. 118-151.

Reagan, T.G. 2002. Language planning and language policy: Past, present and future. In R. Mesthrie (ed.) Language in South Africa. Cambridge: Cambridge University Press. pp. 419433.

Ricento, T. 2007. Models and approaches in language policy and planning. In M. Hellinger and A. Pauwels (eds.) Handbook of language and communication: Diversity and change. Berlin: Mouton de Gruyter. pp. 211-240.

Romaine, S. 2007. Linguistic diversity and language standardization. In M. Hellinger and A. Pauwels (eds.) Handbook of language and communication: Diversity and change. Berlin: Mouton de Gruyter. pp. 685-713.

Schiffman, H.F. 1998. Standardization or restandardization: The case for "standard" spoken Tamil. Language in Society 27(3): 359-385. 
Senekal, J.H. 1984. Afrikaans: 'n Toekomsblik. In K.P. Prinsloo and M.C.J. van Rensburg (eds.) Afrikaans: Stand, taak, toekoms. Pretoria: HAUM. pp. 212-228.

Simango, S.R. 2002. The possibility of harmonising Bantu orthographies. In K.K. Prah (ed.) Speaking in unison: The harmonisation and standardisation of Southern African languages. Cape Town: CASAS. pp. 63-75.

Sonn, F.A. 1990. D.F. Malherbe-gedenklesing 9: Die toekoms van Afrikaans. Acta Varia 1: 1-15.

Stander, M. and A.G. Jenkinson. 1993. Geïnstitusionaliseerde taal binne 'n nuwe bedeling. South African Journal of Linguistics 11(1): 30-37.

Stroop, J.P.A. 1992. Towards the end of the standard language in the Netherlands. In J.A. van Leuvensteijn and J.B. Berns (eds.) Dialect and standard language in the English, Dutch, German and Norwegian language areas. Amsterdam: Koninkljike Nederlandse Akademie van Wetenschappen. pp. 162-177.

Swanepoel, P.H. 1995. Afrikaans taalkunderonderrig op skool in 'n meertalige, multikulturele post-apartheid Suid-Afrika. In H. Ester and A. van Leuvensteijn (eds.) Afrikaans in een veranderende context. Taalkundige en letterkundige aspecten. Amsterdam: Suid-Afrikaanse Instituut. pp. 57-80.

Thompson, J.B. 1991. Editor's introduction. In J.B. Thompson (ed.) Language and symbolic power. Cambridge: Polity Press. pp. 1-31.

Thorburn, T. 1971. Cost-benefit analysis in language planning. In J. Rubin and B.H. Jernudd (eds.) Can language be planned? Sociolinguistic theory and practice for developing nations. Honolulu: The University Press of Hawaii. pp. 253-262.

Van de Rheede, I. 1985. Kaapse Afrikaans: Sosio-politieke perspektief. In J.F. Smith, A. van Gensen and H. Willemse (eds.) Swart Afrikaanse skrywers. Cape Town: University of the Western Cape Press. pp. 34-39.

Van der Horst, J. 2008. Het einde van de standaardtaal. Een wisseling van Europese taalcultuur. Amsterdam: J.M. Meulenhoff.

Van der Horst, J. 2009. Het einde van de standaardtalen. Paper presented at the "Standaardtalen in beweging. Standaardisatie en destandaardisatie in Nederland, Vlaanderen en Zuid-Afrika" symposium, 19-21 August 2009, Leiden University, Leiden.

Van der Wal, M.J. 1995. De moedertaal centraal. Standaardisatie-aspecten in de Nederlanden omstreeks 1650. The Hague: Sdu Uitgevers.

Van Keymeulen, J. 2010. Standaardisatie en destandaardisatie bij Vlamingen en Afrikaners: Parallellen en verschillen. In M. van der Wal and E. Francken (eds.) Standaardtalen in beweging. Amsterdam: Stichting Neerlandistiek VU. pp. 135-152. 
Van Rensburg, C. 1992. Die demokratisering van Afrikaans. In V.N. Webb (ed.) Afrikaans ná apartheid. Pretoria: J.L. van Schaik. pp. 181-197.

Van Rensburg, M.C.J. 1983. Inleiding: Die bestudering van taalvariante. In G.N. Claassen and M.C.J. van Rensburg (eds.) Taalverskeidenheid. 'n Blik op die spektrum van taalvariasie in Afrikaans. Pretoria: Academica. pp. 7-25.

Van Rensburg, M.C.J. 1984. Afrikaans - Die pad vorentoe. In K.P. Prinsloo and M.C.J. van Rensburg (eds.) Afrikaans: Stand, taak, toekoms. Pretoria: HAUM. pp. 177-194.

Vikør, L.S. 1989. The position of standardized vs. dialectal speech in Norway. International Journal of the Sociology of Language 80: 41-59.

Wade, R.D. 1996. An investigation of the putative restandardisation of South African English in the direction of a 'new' English, Black South African English. Unpublished MA thesis. Durban: University of Natal.

Webb, V. 1997. Afrikaans in een democratiserend Zuid-Afrika. Ons Erfdeel 40(2): 225-236.

Webb, V. 2000. Die rekonstruksie van die Afrikaanse werklikheid en handboekvernuwing: Repliek op Jan Esterhuyse. In T. du Plessis and A. van Gensen (eds.) Taal en stryd 1989-1999: Gedenkbundel. Pretoria: Van Schaik. pp. 59-68.

Webb, V. 2005. The role of language standardisation in the effective development of communities in public life in SA. In V. Webb, A. Deumert and B. Lepota (eds.) The standardisation of African languages in South Africa. Pretoria: PanSALB. pp. 35-42.

Webb, V. 2006. On a normative approach to language planning in South Africa. In V. Webb, and L. du Plessis (eds.) The politics of language in South Africa. Pretoria: Van Schaik. pp. 147163.

Webb, V. 2010. Standaardafrikaans: 'n Vurk in die pad? 'n Taalpolitieke perspektief. In M. van der Wal and E. Francken (eds.) Standaardtalen in beweging. Amsterdam: Stichting Neerlandistiek VU. pp. 193-214.

Weinstein, B. 1990. Language policy and political development: An overview. In B. Weinstein (ed.) Language policy and political development. Norwood, New Jersey: Ablex Publishing Corporation. pp. 1-21.

Willemse, H. 2009. Verandering en toekoms: Om 'n kreoolse Afrikaans te bedink. Paper presented at the "Roots" conference, 22-23 September 2009, University of the Western Cape, Bellville.

Williamson, K. and R. Blench. 2000. Niger-Congo. In B. Heine and D. Nurse (eds.) African languages: An introduction. Cambridge: Cambridge University Press. pp. 11-42. 